\title{
THE CORRELATION BETWEEN WATER, SANITATION, AND HYGIENE WITH SOIL-TRANSMITTED HELMINTHS INFECTION AMONG ELEMENTARY SCHOOL CHILDREN OF ARU ISLANDS DISTRICT, MALUKU
}

\author{
Tiffany Konstantin ${ }^{1}$, Indah Setyawati Tantular ${ }^{2}$, Alpha Fardah Athiyyah ${ }^{3}$, Lynda Rossyanti ${ }^{2}$ \\ ${ }^{1}$ Faculty of Medicines, Airlangga University, Surabaya Indonesia \\ ${ }^{2}$ Departement of Parasitology, Faculty of Medicines, Airlangga University, Surabaya, Indonesia \\ ${ }^{3}$ Departement of Child Health Sciene, Dr. Soetomo General Hospital, Surabaya, Indonesia \\ Correspondence Address: Tiffany Konstantin \\ Email: tiffanykonstantin@yahoo.com
}

\begin{abstract}
Soil-Transmitted Helminths (STH) infection is the most common intestinal parasite infection in Indonesia. STH infection can interfere with child development and cause cognitive impairment in severe cases. The school-age group is the most susceptible to STH infection because of direct contact with soil in the school yard. STH infection incidence can be avoided by adequate water, healthy latrines, and good hygiene and can be improved by proper interventions. This study aimed to analyze the correlation between Water, Sanitation, and Hygiene (WASH) with STH infection in Aru Islands District, Maluku. This study used a cross-sectional design and was conducted in Elementary Schools in Karangguli and Wokam villages, Aru Islands district, Maluku. One hundred and six stool samples were collected from both villages. The sociodemographic and WASH data were collected using the interview method. Stool samples were collected and examined for STH infection using a direct smear technique on the light microscope. Data statistical analysis was performed by the SPSS program using the Chi-square or Fischer's Exact test. The examination results showed that 73 students (68.9\%) were infected with STH. The bivariate analysis showed that water source $(p=0.000002)$, defecation place $(p=0.002)$, and washing hands after defecation $(\mathrm{p}=0.048)$ were all significantly correlated with STH infection. This study concluded that WASH variables which were water source, defecation place, and washing hands after defecation had a significant correlation with STH infection.
\end{abstract}

Keywords: Water, Sanitation, and Hygiene (WASH); soil-transmitted helminths infection; elementary school students.

\section{INTRODUCTION}

Helminthiasis is one of the most common infectious diseases in the world, especially in developing countries due to poor sanitation and low awareness of a healthy lifestyle. The most dominant helminthiasis is the Soil-Transmitted Helminths (STH) due to the quick eggs or larvae transmission fecal-orally or through the skin. There are more than 1.5 million people infected by STH up to now, distributed in tropical and subtropical regions, especially in warm and moist places (World Health Organization, 2017).

STH infection usually causes mild gastrointestinal symptoms that can be easily treated using recent drugs. However, STH infection can become severe if left untreated. Severe infection is accompanied by symptoms such as stomachache, loss of blood and protein, rectal prolapse, and impaired cognitive development (Centers for Disease Control and Prevention, 2013). According to experimental research, worms inside the digestive tract can change the composition of gut microbiota and impair food absorption leading to malnutrition. Furthermore, the composition changes of gut microbiota may trigger the human vulnerability to the pathogenic bacteria causing coinfection (Glendinning et al., 2014).

The school-age group has a high susceptibility to STH infection due to the direct contact with soil, as in the schoolyard. Moreover, elementary school students do not have enough awareness of personal hygiene and sanitation (Samarang, Nurjana, and Sumolang, 2016). Besides, 
poor sanitation in school toilets and improper sewage systems can facilitate STH transmission through stools carrying the STH eggs to students who do not wash their hands after defecation. A study in Malaysia showed that STH infection prevalence was higher among people who had no toilets or used the shared ones. However, people may avoid using shared or poorly maintained toilets and prefer to defecate in a river resulting in water pollution (Rajoo et al., 2017).

Indonesia is the fourth populous country in the world. However, the uneven population distribution causes social inequalities, including economy, health facilities, food availability, and education. This gap creates a social imbalance and a high number of poor people, reaching 26.58 million in September 2017 (Central Body of Statistics, 2018). Poverty is the root of STH infection due to its correlation with sanitation, food and clean water availability, education, and hygiene behavior in the community (Sanchez et al., 2016). Yet, sanitation, clean water, and hand washing are associated with a low incidence of STH infection (Strunz et al., 2014).

Common species of STH in Indonesia are Ascaris lumbricoides, Trichuris trichiura, and hookworms (Ancylostoma duodenale and Necator americanus). The prevalence of STH infection, according to a study in 2005, was $49.02 \%$ in North Jakarta, $15.45 \%$ in South Jakarta, 33.2\% in West Jakarta, and 9.37\% in East Jakarta. Thus, it can be concluded that the STH infection has a quite high prevalence and variant distribution in different regions (Mardiana and Djarismawati, 2012).

Maluku is a unique province formed of many small islands in Indonesia. Maluku has the fourth-highest poverty rate among Indonesian provinces (19.26\%) (Central Body of Statistics, 2018). Poverty triggers STH infection due to the inability to obtain a good education, adequate number of shelters, and nutritious food (Sanchez et al., 2016).

Dobo is the capital city of the Aru Islands District in Maluku. Environmental health indicators in the operational areas of the Dobo Primary Healthcare Center are below the standards with a percentage of $30.6 \%$ healthy homes, $98.6 \%$ families with clean water accessibilities, $1.9 \%$ families with wastewater disposal facilities, and $13.3 \%$ families with standard latrines. Villages in the operational areas of the Dobo Primary Healthcare Center are distributed in many small islands around Dobo city including Karangguli and Wokam villages. Unfulfilled healthy home indicators and improper conditions in rural areas are accompanied by a high prevalence of STH infection. The infection rate increases in areas with poor environmental management and low infrastructure development (Waris, Rahayu, and Indriyati, 2012).

Since 2014, the helminthiasis control program providing albendazole has been conducted twice a year targeting the preschool and elementary school children (1 -12 years old) in all operational areas of the Dobo Primary Healthcare Center. In 2017, the program coverage in the Dobo Primary Healthcare Center was $96 \%$ targeting 3257 children, 3135 of them were successful. This program has merely been evaluated through the program coverage proportion. However, the number of STH infection cases after drug intake in the operational areas of the Dobo Primary Healthcare Center is not available yet due to the lack of routine stool examinations. However, the evaluation can be used to estimate the capability of the helminthiasis control program in overcoming the problem (Indonesian Ministry of Health, 2017a).

The number of STH infection cases in the operational areas of the Dobo Primary Healthcare Center is unknown up to now. However, the data are needed to determine the frequency of STH infection among children in relation to factors such as Water, Sanitation, and Hygiene (WASH), and 
evaluate the effectiveness of the existing helminthiasis control program (Zerdo, Yohanes, and Tariku, 2016). Hence, this study aimed to analyze a relationship between WASH and STH infection among elementary school students in Karangguli and Wokam villages, Aru Islands District, Maluku.

\section{METHODS}

This study was an analytical observational study using a cross-sectional design. The analytical observational study aims to analyze the correlation between the variables without a direct intervention. This study analyzed the correlation between Water, Sanitation, and Hygiene (WASH) and Soil-Transmitted Helminths (STH) infection among elementary school students in Karangguli and Wokam villages. The study used the cross-sectional design to collect and analyze data in one-point time.

The study population was students from Karangguli Public Elementary School and Wokam Public Elementary School, Aru Islands District with total numbers of 55 and 79 students consecutively in 2018. The study used the total sampling technique. The study included students who had the will to participate and excluded students who did not collect their stool samples or those who did not answer all the interview questions.

This study was conducted in August 2018. One hundred and six stool samples were collected from both villages. Interviews with the students and their parents were conducted to collect data on last anthelmintic drug administrations; sociodemographic variables (age, gender, grade, parents' last education, and parents' occupation); water variables (physical characteristics of water quality, water source, and boiled drinking water); sanitation variable (defecation place); and hygiene variables (handwashing before eating, handwashing with soap, handwashing after defecation, handwashing after playing with soil/dirt, cutting nails routinely, wearing footwear outdoors, and playing with soil/dirt). Collected stool samples were analyzed to check STH species according to the presence of STH eggs or larvae (Ascaris lumbricoides, Trichuris trichiura, and/or hookworms) using a light microscope with a direct smear technique. Data on WASH and STH infection were analyzed by the SPSS program using the Chi-square or Fischer's Exact test if the Chi-square could not be used. The bivariate statistical analysis would show the relationship between WASH variables and STH infection was significant if a p-value was $<0.05$. Contingency coefficient score was used to determine the strength of the correlation among significant variables.

This study ethical permission was approved by the Research Ethics Committee, Faculty of Medicine, Universitas Airlangga with an ethical clearance number of 189/EC/KEPK/FKUA/2018. The subjects' parents were given written information and asked for informed consent regarding the data collection.

\section{RESULTS}

Out of the 106 students, 73 students were infected $(68.9 \%)$ and 33 students were not $(31.1 \%)$ with STH. Based on STH species, the number of students infected with Ascaris lumbricoides was 56 students, with Trichuris trichiura was 50 students, and with hookworms was 12 students. Of all students, 31 students had a single infection, 33 students had a double infection, and 6 students had a triple infection. The distribution of STH species is shown in Table 1.

Table 1. Distribution of STH Species

\begin{tabular}{lc}
\hline \multicolumn{1}{c}{ STH Species } & $\begin{array}{c}\text { Total }(\mathbf{n}=\mathbf{7 3}) \\
(\mathbf{\%})\end{array}$ \\
\hline $\begin{array}{l}\text { Ascaris lumbricoides } \\
\text { and Trichuris trichiura }\end{array}$ & $27(36.9)$ \\
$\begin{array}{l}\text { Ascaris lumbricoides } \\
\text { and hookworms }\end{array}$ & $4(5.4)$
\end{tabular}


Trichuris trichiura and hookworms

Ascaris lumbricoides,

Trichuris trichiura, $\quad 6(8.2)$ and hookworms

Ascaris lumbricoides 19 (26)

Trichuris trichiura 15 (20.5)

The helminthiasis control program in both villages was conducted in February and August every 6 months since 2014. A total of 89 students took the anthelmintic drug in the past 6 months as this study was conducted in early August, while the next program was conducted in the following month. The other 17 students did not take the drug in the past six months but in the past 12 months during the previous program.

The sociodemographic distribution of subjects is presented in Table 2. The percentage of STH infection was a bit higher in males $(69.2 \%)$ than females $(68.5 \%)$. The highest percentage of STH infection was in Grade I (73.3 \%) followed by Grade VI (72.2\%), II (70.6\%), III $(68.8 \%)$, IV (65.4\%), and V (64.3\%). The average age of subjects was 8.75 years, the youngest ( 6 years old) and the oldest (13 years old). The percentage of STH infection was higher among students aged 10 years old or older $(74.3 \%)$ compared to others under 10 years old $(65.6 \%)$.

Table 2. Sociodemographic Distribution of the Subjects

\begin{tabular}{lccc}
\hline \multicolumn{1}{c}{$\begin{array}{c}\text { Sociodemographics of the } \\
\text { Subjects }\end{array}$} & \multicolumn{2}{c}{ STH Infection } & Total (n= 106) \\
\cline { 2 - 3 } & Infected (\%) & Not Infected (\%) & \\
\hline Gender & $36(69.2)$ & $16(30.8)$ & $52(49.1)$ \\
Male & $37(68.5)$ & $17(31.5)$ & $54(50.9)$ \\
Female & & & \\
Grade & $11(73.3)$ & $4(26.7)$ & $15(14.2)$ \\
I & $12(70.6)$ & $5(29.4)$ & $17(16.0)$ \\
II & $11(68.8)$ & $5(31.2)$ & $16(15.1)$ \\
III & $17(65.4)$ & $9(34.6)$ & $26(24.5)$ \\
IV & $9(64.3)$ & $5(35.7)$ & $14(13.2)$ \\
V & $13(72.2)$ & $5(278)$ & $18(17.0)$ \\
VI & & & \\
& & & \\
Age (years) & $10(71.4)$ & $4(28.6)$ & $14(13.2)$ \\
6 & $8(61.5)$ & $5(38.5)$ & $13(12.3)$ \\
7 & $14(66.7)$ & $7(33.3)$ & $21(19.8)$ \\
8 & $12(63.2)$ & $7(36.8)$ & $19(17.9)$ \\
9 & $17(77.3)$ & $5(22.7)$ & $22(20.8)$ \\
10 & $9(63.2)$ & $4(30.8)$ & $13(12.3)$ \\
11 & $2(100)$ & $0(0)$ & $2(1.9)$ \\
12 & $1(50)$ & $1(50)$ & $2(1.9)$ \\
13 & & & \\
\hline
\end{tabular}

The sociodemographic distribution of subjects' parents is presented in Table 3. The highest percentage of STH infection was among students whose parents did not finish elementary school (100\%) while the lowest percentage was among subjects whose parents finished college education $(60 \%)$. The highest percentage of STH infection was among students whose parents were farmers $(75.3 \%)$, followed by fishermen (70\%), and government employees $(42.1 \%)$. 
Table 3. Sociodemographic Distribution of the Subjects' Parents

\begin{tabular}{lccc}
\hline \multicolumn{1}{c}{$\begin{array}{c}\text { Sociodemographics of the } \\
\text { Subjects' Parents }\end{array}$} & \multicolumn{2}{c}{ STH Infection } & Total (n=106) \\
\cline { 2 - 3 } & Infected (\%) & Not Infected (\%) & \\
\hline Lastest Education & $1(100)$ & $0(0)$ & $1(0.9)$ \\
Not completed Elementary School & $17(65.4)$ & $9(34.6)$ & $26(24.5)$ \\
Elementary School & $24(80)$ & $6(20)$ & $30(28,3)$ \\
Junior High School & $22(64.7)$ & $12(35.3)$ & $34(32.1)$ \\
Senior High School & $9(60)$ & $6(40)$ & $15(14.2)$ \\
College & & & \\
& & & \\
Occupation & $7(70)$ & $3(30)$ & $10(9.4)$ \\
Fishermen & $8(42.1)$ & $11(57.9)$ & $19(17.9)$ \\
Government Employees & $58(75.3)$ & $19(24.7)$ & $77(72.6)$ \\
Farmers & & & \\
\hline
\end{tabular}

Data on water variables and the bivariate analysis results are presented in Table 3. Water variables include the water source, physical water quality, and boiled drinking water. The Chi-square test was used to determine the correlation between all water variables and STH infection. Results showed that 26 students used inadequate physical water quality. Nevertheless, all students consumed boiled drinking water.

In this study, the water sources were piped water, dug wells, rainwater, and spring water. The percentage of STH infection from high to low based on the water source was piped water $(95 \%)$, spring water $(85.1 \%)$, dug wells $(62.5 \%)$, and rainwater $(0.9 \%)$, consecutively. The Chisquare test results showed that the correlation between the water source and STH infection was significant $(\mathrm{p}=$ 0.000002). The correlation strength was then assessed using a contingency coefficient score (0.463); thus, the correlation strength was moderate.

Table 3. Bivariate Analysis of Water Variables and STH Infections

\begin{tabular}{lcccc}
\hline \multirow{2}{*}{ Water Variables } & \multicolumn{2}{c}{ STH Infection } & Total & $\begin{array}{c}\text { p- } \\
\text { value }\end{array}$ \\
\cline { 2 - 3 } Physical Water Quality & Infected (\%) & Not Infected (\%) & $(\%)$ & \\
Adequate & $56(70)$ & $24(30)$ & $80(75.5)$ & 0.659 \\
Inadequate & $17(65.4)$ & $9(34.6)$ & $26(24.5)$ & \\
Water Source & & & & \\
Piped water & $19(95)$ & $1(5)$ & $20(18.8)$ & $<0.000$ \\
Dug wells & $30(62.5)$ & $18(37.5)$ & $48(45.3)$ & \\
Rainwater & $1(0.9)$ & $10(99.1)$ & $11(10.4)$ & \\
Spring water & $23(85.1)$ & $4(14.9)$ & $27(25.5)$ & \\
Boiled drinking water & & & & \\
Yes & $73(68.9)$ & $33(31.1)$ & $106(100)$ & N/A \\
No & $0(0)$ & $0(0)$ & $0(0)$ & \\
\hline
\end{tabular}

The bivariate analysis between sanitation and STH infection is presented in Table 4. Defecation place was classified into three categories: land or sea, shared latrines, and private latrines. The percentage of STH infection was $84.6 \%$, 
$50 \%$, and $59 \%$ among students who defecated on land or sea, in private latrines, and shared latrines, respectively. Chisquare results reflected the significant correlation between defecation place and
STH infection $(\mathrm{p}=0.002)$. Then, the correlation strength was assessed using the contingency coefficient score $(0.323)$, and thus the correlation strength was moderate

Table 4. Bivariate Analysis of Sanitation Variable and STH Infection

\begin{tabular}{|c|c|c|c|c|}
\hline \multirow{2}{*}{ Sanitation Variable } & \multicolumn{2}{|c|}{ STH Infection } & \multirow{2}{*}{$\begin{array}{c}\text { Total } \\
(\%)\end{array}$} & \multirow{2}{*}{$\begin{array}{c}\text { p- } \\
\text { value }\end{array}$} \\
\hline & Infected (\%) & Not Infected (\%) & & \\
\hline \multicolumn{5}{|l|}{ Defecation Place } \\
\hline Land/sea & $44(84.6)$ & $8(15,4)$ & $52(49.1)$ & 0.002 \\
\hline Shared latrines & $13(59)$ & $9(41)$ & $22(20.7)$ & \\
\hline Private latrines & $16(50)$ & $16(50)$ & $32(30.2)$ & \\
\hline
\end{tabular}

Table 5. Bivariate Analysis of Hygiene Variable and STH Infection

\begin{tabular}{lcccc}
\hline \multirow{2}{*}{ Hygiene Variable } & \multicolumn{2}{c}{ STH Infection } & \multirow{2}{*}{ Total (\%) } & $\begin{array}{c}\text { p- } \\
\text { value }\end{array}$ \\
\cline { 2 - 3 } & Infected (\%) & Not Infected (\%) & & \\
\hline Handwashing before eating & $36(65.5)$ & $19(34.5)$ & $55(51.9)$ & 0.431 \\
Always & $37(72.5)$ & $14(27.5)$ & $51(48.1)$ & \\
Not always & & & &
\end{tabular}

Handwashing with soap

Always

Not always

$39(66.1)$

$34(72.3)$

$20(33.9)$

13 (27.7)

$59(55.7)$

$47(44.3)$

$\underline{\text { Handwashing after }}$

defecation

Always

$34(59.6)$

39 (79.6)

$23(40.4)$

$10(20.4)$

$57(53.8)$

0.027

Not always

$\underline{\text { Handwashing after playing }}$

with soil/dirt

Always

Not always

$31(63.3)$

42 (73.7)

$18(36.7)$

$15(26.3)$

$49(46.2) \quad 0.248$

$57(53.8)$

Cutting nails routinely

Always

$38(69.1)$

17 (30.9)

55 (51.9)

0.959

Not always

Wearing footwear outdoors

Always

Not always

Playing with soil/dirt

Always

Not always
35 (68.6)

$16(31.4)$

$25(64.1)$

48 (71.6)

$68(67.3)$

$5(100)$

$14(35.9)$

39 (36.8) $\quad 0.419$

$19(28.4) \quad 67(63.2)$

$51(48.1)$

$101(95.3) \quad 0.322$ 5 (4.7) 
The Bivariate analysis between hygiene variables and $\mathrm{STH}$ infection is presented in Table 5. The percentages of STH infection were $65.5 \%, 72.5 \%, 66.1 \%$, and $72.3 \%$ among students who always washed their hands before eating; who did not always wash their hands before eating; who always washed their hands using soap; and who did not always wash their hands using soap, respectively. These two variables had no significant correlation with STH infection according to the Chi-square test results.

The percentage of STH infection among students who did not always wash their hands after defecation $(79.6 \%)$ was higher than others who always did (59.6\%).

The Chi-square test showed that the correlation between washing hands after defecation and STH infection was significant $(\mathrm{p}=0.027)$. The contingency coefficient score $(0.210)$ reflected a weak correlation among the variables.

Based on interviews, the percentage of STH infection was higher in students who did not always wash their hands after playing with soil/dirt $(73.7 \%)$ than those who always did (63.3\%). However, the Chisquare test showed no significant correlation between handwashing habit after playing with soil/dirt and STH infection.

The interview showed that the percentage of STH infection among students who always cut their nails routinely once a week was higher than those who did not. However, no significant correlation among variables was determined according to the Chi-square test.

Data also stated that the percentage of STH infection was lower among students who always used footwear outdoors $(64.1 \%)$ than others who did not $(71.6 \%)$. The statistical analysis with the Chi-square test showed no significant correlation between footwear use outdoors and STH infection.

Based on the interview data, the number of students who always played with soil/dirt was 101 students, and 68 of them had STH infection. On the other hand, all students who did not always play with soil/dirt were infected by STH. The statistical results using the Fischer's Exact test showed no significant correlation among the variables $(\mathrm{p}=0.322)$.

\section{DISCUSSION}

The STH infection prevalence among elementary school students in Wokam and Karangguli villages was $68.9 \%$. In these two villages, the helminthiasis control program was implemented in February and August by administering Albendazole 400 mg every 6 months. The study data were collected in early August before the August helminthiasis control program. Therefore, most students got the drug 6 months before data collection while the others got the drug12 months. This study showed that STH infection was higher among students who took the drug more than 6 months ago compared to those who took it in the last 6 months. Nevertheless, STH prevalence (> $50 \%$ ) is considered high according to the Indonesian Ministry of Health (Indonesian Ministry of Health, 2017a).

A study in Uganda showed a significant decrease in STH infection prevalence and intensity after biannual helminthiasis control program application (Adriko et al., 2018). However, after a short time of treatment, STH re-infection occurred especially for Trichuris trichiura and Ascaris lumbricoides species. Thus, integrated preventive treatment along with hygiene and sanitation interventions using health education is mandatory to reduce STH infection prevalence (Jia et al., 2012).

In this study, the Chi-square test showed no significant correlation between the physical water quality and the STH examination results in the two villages. Despite adequate physical water quality, many students were infected with STH as a result of other STH transmission factors. All students were drinking water after 
boiling. However, a meta-analysis study approved that drinking boiled water was accompanied by lower STH infection rate (Strunz et al., 2014).

The highest percentage of STH infection was among students whose water source was piped water, followed by water springs, dug wells, and rainwater. The bivariate analysis with the chi-square test results showed a significant correlation between the water source and STH infection, but the correlation was weak with a contingency coefficient score of 0.463 . This result opposed the theory which categorized the piped water as a clean and safe source. A meta-analysis study showed that piped water source was associated with low STH infection caused by both Ascaris lumbricoides and Trichuris trichiura, but not hookworms (Strunz et al., 2014). The high percentage of STH infection among students who use piped water can be related to poor water quality in pipes in rural areas (Belyhun et al., 2010). Based on the observation of the study locations, the used piped water was from mountains not from the Regional Water Company (PDAM) with no further treatment, and the water was stored in the household water tanks increasing the possibility of water being contaminated. Water tanks in both villages were not closed and usually located beside latrines. This might stimulate STH infection among students who used piped water. Rainwater reservoirs, based on observations in this study, were also located next to houses and not near latrines. The low prevalence of STH infection among students who used rainwater was related to the closed water storage with low exposure to contamination. A high percentage of STH infection among students whose water sources came from water springs and wells were related to wells and water springs that were open and located close to the ground surface exposing them to contamination. A study in Kenya found that using pre-treated water was one of the protective factors against STH infection (Worrell et al., 2016).
The sanitation variable in this study was the defecation place. The results showed that most students were mostly defecating on land or sea, followed by private latrines and shared latrines. The Chi-square test showed a significant correlation between defecation place and STH infection. This goes along with a study conducted in 2018 where higher STH infection was among students who did not defecate in a latrine. Open defecation is accompanied by soil contamination that makes a favorable environment for the growth of STH eggs and larvae that can enter the body through food, drink, or the skin. Similar to this study, a study in Kenya also found that higher STH infection was among students who defecated in shared latrines (Worrell et al., 2016). This was inferred to poor cleanliness of shared toilets accompanied by high exposure to STH eggs since more people use latrine toilets more than private ones (Steinbaum et al., 2019).

The bivariate analysis results showed no significant correlation between the habit of washing hands before eating or washing hands with soap with STH infection. This opposes a study in Ethiopia where STH infection was higher in the group who did not wash their hands before eating. Washing hands can prevent STH transmission especially in Ascaris lumbricoides and Trichuris trichiura species since the eggs can attach to hands or nails and then enter the body with food (Alelign, Degarege, and Erko, 2015). The percentage of STH infection was higher in the group that did not always wash their hands before eating or using soap than the group that always did, but the correlation was not significant. A meta-analysis study found that washing hands with soap was one of the protective factors against STH infection (Strunz et al., 2014).

Students who did not always wash their hands after defecation had a higher percentage of STH infection than others who always did. The bivariate analysis using the chi-square test showed a significant correlation between washing 
hands after defecation and STH infection. This result is confirmed by a study in rural Uganda where the STH infection possibility was 2.6 times more in the group that rarely washed their hands after defecation where STH transmission might occur fecal-orally or through the skin. STH eggs attach to nonwashed hands or nails after defecating followed by transmission to the mouth (Ojja et al., 2018).

Most students in these two villages always washed their hands after playing with soil/dirt. The bivariate analysis with the chi-square test showed no significant correlation between the habit of washing hands after playing with soil/dirt and STH infection. Nevertheless, STH infection was lower in the group that always washed their hands after playing with soil/dirt compared to the group that did not. However, handwashing habit was associated with a lower prevalence of fecal-oral STH infection (Strunz et al., 2014).

Interviews with students and their parents showed that the majority of students from both villages had the habit of cutting nails routinely once a week. The chi-square test showed no significant correlation between the habit of cutting nails routinely and STH infection. However, a study in Medan showed that not cutting nails routinely was one of the risk factors for STH infection since nails could contain soil depositions that may have STH eggs which are difficult to clean (Wiryadana et al., 2018). The insignificant results could be inferred to the presence of other hygiene factors affecting STH transmission such as hand washing. This was consistent with a case in Salatiga where no significant relationship was found between nail hygiene and STH infection but with handwashing habits instead (Sofiana, 2010).

The majority of students in these two villages had the habit of playing with soil/dirt (95.2\%). The bivariate analysis with the Fischer's Exact test showed no significant correlation between the habit of playing with soil/dirt and STH infection.
This was related to other hygiene factors that influence STH infection such as hand washing and footwear use. In this study, most students did not wear footwear outdoors $(63.2 \%)$. The Chi-square test showed no significant correlation between footwear wearing outdoors and STH infection. However, the percentage of STH infection was higher in the group who did not always use footwear outdoors than those who always did. These results were confirmed by a study in Medan, where no significant correlation was found between playing habits with soil/dirt and STH infection, but a significant correlation with footwear use (Wiryadana et al., 2018). The habit of playing with soil/dirt and using footwear was also associated with hookworms infection more than infection with Ascaris lumbricoides and Trichuris trichiura (Strunz et al., 2014). In this study, the non-significant correlation between STH infection and footwear habit or playing with soil/dirt was inferred to the low hookworm infection.

\section{CONCLUSION}

It can be concluded that the prevalence of STH infection among students in Elementary Schools of Karangguli and Wokam villages was $68.9 \%$ in 2018. Moreover, the WASH variables that had significant correlations with STH infection were water source, defecation place, and the habit of washing hands after defecation. The helminthiasis control program has been carried out routinely twice a year. Nevertheless, the persistent high STH infection (> 50\%) could be due to STH re-infection. Therefore, it is necessary to guide students of Karangguli and Wokam Public Elementary Schools to defecate in toilets and wash their hands after defecation. The government could play a crucial role in providing education integrated with helminthiasis control programs to reduce the prevalence of STH infection. 


\section{REFERENCES}

Adriko, M., Tinkitina, B., Arinaitwe, M., Kabatereine, N.B., Nanyunja, M. and M. Tukahebwa, E., 2018. Impact of a national deworming campaign on the prevalence of soiltransmitted helminthiasis in Uganda (2004-2016): Implications for national control programs. PLOS Neglected Tropical Diseases, [online] 12(7), p.e0006520. Available at: $<$ https://doi.org/10.1371/journal.pnt d.0006520>.

Alelign, T., Degarege, A. and Erko, B., 2015. Soil-Transmitted Helminth Infections and Associated Risk Factors among Schoolchildren in Durbete Town, Northwestern Ethiopia. Journal of Parasitology Research, [online] 2015(641602). Available at: <https://doi.org/10.1155/2015/6416 $02>$.

Belyhun, Y., Medhin, G., Amberbir, A., Erko, B., Hanlon, C., Alem, A., Venn, A., Britton, J. and Davey, G., 2010. Prevalence and risk factors for soil-transmitted helminth infection in mothers and their infants in Butajira, Ethiopia: a population based study. $B M C$ Public Health, [online] 10(1), p.21. Available at: $<$ https://doi.org/10.1186/14712458-10-21>.

Central Bureau of Statistics, 2018. Persentase Penduduk Miskin September 2017 Mencapai 10,12 persen. Jakarta: Central Bureau of Statistics.

Centers for Disease Control and Prevention, 2013. Parasites. [online]

Dobo Public Health Center, 2017. Profil Puskesmas Dobo Tahun 2016. Dobo: Puskesmas Dobo.

Indonesian Ministry of Health, 2015. Laporan Akuntabilitas Kinerja Tahun 2014. Jakarta: Indonesian
Ministry of Health.

Indonesian Ministry of Health, 2017a.

Peraturan Menteri Kesehatan Republik Indonesia Nomor 15

Tahun $2017 \quad$ Tentang

Penanggulangan Cacingan.

Jakarta: Indonesian Ministry of Health.

Indonesian Ministry of Health, 2017b. Profil Kesehatan Indonesia Tahun 2016. Jakarta: Indonesian Ministry of Health.

Jia, T.-W., Melville, S., Utzinger, J., King, C.H. and Zhou, X.-N., 2012. SoilTransmitted Helminth Reinfection after Drug Treatment: A Systematic Review and Meta-Analysis. PLOS Neglected Tropical Diseases, [online] 6(5), p.e1621. Available at: $<$ https://doi.org/10.1371/journal.pnt d.0001621>.

Glendinning, L., Nausch, N., Free, A., Taylor, D.W. and Mutapi, F., 2014. The microbiota and helminths: sharing the same niche in the human host. Parasitology, [online] 141(10), pp.1255-1271. Available at:

<doi:10.1017/S0031182014000699 $>$.

Mardiana, M. and Djarismawati, D., 2012. Prevalensi Cacing Pada Murid Sekolah Dasar Wajib Belajar Pelayanan Gerakan Terpadu Pengentasan Kemiskinan Daerah Kumuh di Wilayah DKI Jakarta. Jurnal Ekologi Kesehatan, [online] 7(2 August).

Ojja, S., Kisaka, S., Ediau, M., Tuhebwe, D., Kisakye, A.N., Halage, A.A., Mugambe, R.K. and Mutyoba, J.N., 2018. Prevalence, intensity and factors associated with soiltransmitted helminths infections among preschool-age children in Hoima district, rural western Uganda. BMC Infectious Diseases, [online] 18(1), p.408. Available at: $<$ https://doi.org/10.1186/s12879018-3289-0>. 
Rajoo, Y., Ambu, S., Lim, Y.A.L., Rajoo, K., Tey, S.C., Lu, C.W. and Ngui, R., 2017. Neglected Intestinal Parasites, Malnutrition and Associated Key Factors: A Population Based Cross-Sectional Study among Indigenous Communities in Sarawak, Malaysia. PLOS ONE, [online] 12(1), p.e0170174. Available at: <https://doi.org/10.1371/journal.po ne.0170174>.

Samarang, Nurjana, M.A. and Sumolang, P.P.F., 2016. Prevalensi Soil Transmitted Helminth di 10 sekolah dasar Kecamatan Labuan Kabupaten Donggala Sulawesi Tengah. $J$ Health Epidemiol Commun Dis, 2(2), pp.33-38.

Sanchez, A., Gabrie, J., Canales, M., Rueda, M., Fontecha, G., Mason, P., Bearman, G. and Stevens, M., 2016. Soil-Transmitted Helminths, Poverty, and Malnutrition in Honduran Children Living in Remote Rural Communities. Human Parasitic Diseases, [online] 8, pp.27-35. Available at: $<$ http://dx.doi.org/10.4137/HPD.S3 3458>.

Sofiana, L., 2010. Hubungan Perilaku Dengan Infeksi Soil Transmitted Helminths Pada Anak Sekolah Dasar MI Asas Islam Kalibening, Salatiga. Jurnal Kesmas Universitas Ahmad Dahlan, 4(2), pp.76-143.

Staf Pengajar Departemen Parasitologi Fakultas Kedokteran Universitas Indonesia, 2006. Buku Ajar Parasitologi Kedokteran. Jakarta: Badan Penerbit Fakultas Kedokteran Universitas Indonesia.

Steinbaum, L., Mboya, J., Mahoney, R., Njenga, S.M., Null, C. and Pickering, A.J., 2019. Effect of a sanitation intervention on soiltransmitted helminth prevalence and concentration in household soil: A cluster-randomized controlled trial and risk factor analysis. PLOS
Neglected Tropical Diseases, [online] 13(2), p.e0007180. Available at: $<$ https://doi.org/10.1371/journal.pnt d.0007180>.

Strunz, E.C., Addiss, D.G., Stocks, M.E., Ogden, S., Utzinger, J. and Freeman, M.C., 2014. Water, sanitation, hygiene, and soiltransmitted helminth infection: a systematic review and metaanalysis. PLoS medicine, [online] 11(3), pp.e1001620-e1001620. Available at: <https://doi.org/10.1371/journal.pm ed.1001620>.

Waris, L., Rahayu, N. and Indriyati, L., 2012. Risiko Kecacingan Pada Anak Sekolah Dasar di Pedesaan Daerah Perbatasan Kabupaten Nunukan. Jurnal Biotek Medisiana Indonesia, 1(1).

Wiryadana, K.A., Putra, I.W.A.S., Rahayu, P.D.S., Pradnyana, M.M., Adelaida, M.L. and Sudarmaja, I.M., 2018. Risk factors of soil-transmitted helminth infection among elementary school students. Paediatrica Indonesiana, [online] 57(6), pp.295-302. Available at: <https://doi.org/10.14238/pi57.6.20 17.295-302>.

World Health Organization, 2017. Soiltransmitted helminth infections. [online].

Worrell, C.M., Wiegand, R.E., Davis, S.M., Odero, K.O., Blackstock, A., Cuéllar, V.M., Njenga, S.M., Montgomery, J.M., Roy, S.L. and Fox, L.M., 2016. A Cross-Sectional Study of Water, Sanitation, and Hygiene-Related Risk Factors for Soil-Transmitted Helminth Infection in Urban School- and Preschool-Aged Children in Kibera, Nairobi. PloS one, [online] 11(3), pp.e0150744-e0150744. Available at:

<https://doi.org/10.1371/journal.po ne.0150744>. 
Zerdo, Z., Yohanes, T. and Tariku, B., 2016. Soil-Transmitted Helminth Reinfection and Associated Risk Factors among School-Age Children in Chencha District, Southern Ethiopia: A Cross-
Sectional Study. Journal of Parasitology Research, [online] 2016(4737891). Available at: <https://doi.org/10.1155/2016/4737 891>. 